\title{
'We live on estimates': everyday practices of prepaid electricity and the urban condition in Maputo, Mozambique
}

\author{
Idalina Baptista \\ Associate Professor in Urban Anthropology \\ Department for Continuing Education \\ University of Oxford \\ Rewley House, 1 Wellington Square \\ Oxford, OX1 2JA \\ United Kingdom \\ Phone: $+44(0) 1865280153$ \\ E-mail: idalina.baptista@conted.ox.ac.uk
}

\begin{abstract}
:
This article examines the transition to prepaid electricity happening in Maputo, Mozambique to reflect on the contemporary geographies of urban energy infrastructure and urbanization in Sub-Saharan Africa and other cities of the South. Drawing on fieldwork and archival research conducted in 2013 and 2014, the article argues that prepayment constitutes a productive juncture in the urban experience of electricity infrastructure in Maputo's post-colonial moment, not just a neutral technology or a disciplining technique of government (as argued by some scholarship). By focusing on the everyday practices of prepaid electricity of urban dwellers in neighborhoods where the 'modern infrastructural ideal' may never be fully realized, the article examines the multiple rationalities implicated in the use of the electricity infrastructure via prepayment and the organization of urban life it engenders (and of which it is also a product). As a result, the article makes a contribution to understanding the experience of urban energy in cities where 'slum urbanism', uncertainty and provisionality are dominant aspects of the urban condition.
\end{abstract}

Keywords: prepayment, electricity, energy infrastructure, urbanization, Maputo, Mozambique

\section{Acknowledgements}

Fieldwork and archival research was conducted with the support of: Oxford's John Fell Fund grant while the author was the Sir Nigel Mobbs Research Fellow for the Oxford Programme for the Future of Cities; and the Research Fund of Oxford's Department for Continuing Education. For the support in Maputo, I would like to thank Júlio Carrilho, Pedro Coimbra, Sr. Manhiça, Aires Novela, João Tique and, most especially, the members of the Home Space project team, Luís Lage and Paul Jenkins. For their comments to earlier versions of the article, I would like to thank Sophie Haines, Nils Markusson, Catherine Montgomery, Natalie Porter, Steve Rayner, Jonathan D. Silver, Alex Schafran, Gordon Walker, Gisa Weszkalnys, the Editor and three referees. 


\section{Introduction}

'We live on estimates', Manuel declared, as he stood by his second-hand SUV inside the wall-bound driveway of his family's house in bairro Hulene outside the cidade.[1] Manuel's parents built the house in the 1980s with wood planks and a zinc rooftop and gradually upgraded it to cement blocks, adding more rooms as the family grew. The house is now somewhat larger but similar in appearance to neighboring self-built houses. It is located at the intersection of two narrow and bumpy unpaved streets characteristic of Maputo's bairros. Manuel confessed it is a challenge to drive the SUV in and out of the driveway and, at night, with the streets dimly lit, it can be dangerous too. As a universityeducated, state-employed high school teacher, Manuel is among an emerging class of Mozambicans with a small but steady income. Even though he holds a formal job with a certain social status, his income is not in keep with a life of carefree consumption.[2] Like most in Mozambique, Manuel routinely has to add up 'the numbers to see how much is going to be spent on food, charcoal, water, electricity, and so on'. Because they 'didn't have much to spend', Manuel acknowledged that estimation and calculation allowed his family to acquire everything that makes up for a normal life.

What 'everything' or 'normal' entails is not the same for Manuel or his neighbors, but buying electricity using Credelec, Mozambique's prepaid electricity system, is now integral to Maputo's household calculations. According to the state-owned electricity company EDM (Electricidade de Moçambique, E.P.), in 2013, ninety-seven percent of the nearly 1.2 million of the city's estimated population had an electricity connection, with a rate of Credelec users of ninety percent. While being connected to the grid is not the same as being able to consume electricity regularly or liberally, this is an incredible feat in a city where, at independence (1975), the distribution grid was largely restricted to the cidade. Significant investments in the grid were limited until the 2000s, not least due to sixteen years of civil war that further battered the incipient grid the Portuguese left behind. Prepaid electricity was introduced in 1995 to balance EDM's cash-flow problems by recovering debt from non-paying customers. Over time, prepayment lost its discriminatory tenor and is now the default electricity retail model in Maputo. In principle, Credelec is easy: a person goes to a vending shop with whatever money $\mathrm{s} / \mathrm{he}$ has, provides the prepaid meter number to the salesperson and receives a twenty-digit voucher for the corresponding amount of kilowatts-hour $(\mathrm{kWh})$ of electricity. The person then inputs the digits on the meter's keypad to top it up with the kWh acquired. Since late 2013, electricity can also be bought via mobile phones, ATMs, electronic wallet services and on the Internet. According to EDM, this allows customers to acquire electricity 'anytime, anywhere'.

Yet, in a country where grid obsolescence and inefficiency constrain access, with barely enough electricity to go around in face of growing demand, the universality and ubiquity of prepayment holds the promise of future consumption, but not the certainty of utility security. It is in the everyday practices of prepaid electricity that residents of Maputo's bairros secure access to electricity through constant estimation and calculation of when and how much can be bought and consumed. It is through these and other everyday negotiations that urban life in Maputo unfolds and the city's urban condition (re)produced.

This article examines the transition to prepaid electricity happening in Maputo, Mozambique to reflect on the contemporary geographies of urban energy infrastructure and urbanization in SubSaharan Africa and other cities of the South. The article examines prepayment as central to the urban experience in the post-colonial moment, where 'slum urbanism' (Pieterse, 2011), uncertainty and provisionality are the prevalent realities in African cities (Simone, 2004a, Myers, 2011). It conceptualizes prepayment not as a neutral technology or a strictly disciplining technique of government, as argued by some scholarship, but as a productive juncture in the experience of urban energy in cities of the South. By foregrounding the everyday practices of prepaid electricity in the bairros of Maputo, the article highlights how prepayment facilitates negotiations of different social relationships, while also evincing notions of comfort and convenience associated with urban living. Overall, the fragile urbanity embedded in the prepaid electricity grid now being rolled out and universalized in Maputo is both generative and a product of the city's urban condition.

The article is organized in four sections. The next section discusses prepayment in the context of ongoing debates about urban infrastructure, with particular attention to cities of the South, highlighting how this socio-technical transition engages current theorizations of urban energy and 
urbanization more broadly. The second section introduces an historical overview of Maputo's electrification. This contextualizes the examination of prepaid electricity practices of urban dwellers in Maputo's bairros in the third section. The article concludes with a section discussing the implications of the Maputo case to ongoing debates about the politics of urban energy infrastructure in Sub-Saharan African cities and other cities of the South. The article draws on fieldwork conducted in Maputo in 2013 and 2014 and analysis of archival records and of official reports available online. Fieldwork entailed participant observation and semi-structured interviews with thirty households in nine bairros of Maputo (see Figure 2), twenty-five informants at six Credelec vending shops and with fourteen informants related to the electricity sector, eight of which from EDM.[3]

\section{Urban infrastructure, prepayment and cities of the South}

The electricity grid is a large socio-technical system of great complexity and interdependence (Hughes, 1983): a diverse host of social actors (e.g., engineers, providers, state regulators, users) is constantly engaging with and affecting materially, technically, socially and politically the grid's physical parts (e.g., power generation plants, transformers, cables, wires, switches, appliances). As this complex system continued to evolve since inception in late $19^{\text {th }}$-century, electricity inexorably shaped social and economic development the world over, setting new standards and expectations for everyday livelihoods. Alongside urban infrastructures like water, roadways or telecommunications, electricity has played a fundamental role in processes of urbanization and in the regimentation of space, people and resources for capitalist accumulation (Harvey, 1996, Swyngedouw, 1996). The materiality of urban infrastructures is central to how people experience the city. The urban condition is constantly (re)constituted via the flows of people, resources, power, or knowledge through infrastructure networks (Graham and Marvin, 2001). In being icons of civilization and progress (White, 1943) and expressions of modernity and urbanity (Platt, 1991, Melosi, 2000, Gandy, 2004), urban infrastructures have a symbolic and discursive power that shapes social relations, while also being constituted through them (Kaika and Swyngedouw, 2000).

Hence, the technologies and devices through which infrastructures are accessed, such as prepayment, are not neutral technical objects. They reflect a particular politics about social life. Moreover, they are invested with a specific politics about who its users are, what kinds of lives they lead, and their political subjectivity (Akrich, 1992). As a result, they can have a disciplining effect on its users. It has been suggested that utility meters, especially prepaid meters, enforce strict economic relations between users and service providers (Heusden, 2009). Yet, prepayment (or post-payment) and its meters can be more than a proxy for an economic relation. They can constitute a political terrain (Schnitzler, 2013) for the negotiation of broader ethical, cultural, environmental and even spatial relations implicated in the organization of social life (Barry, 2001, Marres, 2012). They can be widely implicated in diverse interactions between users and service providers beyond billing and payments, including new connections, upgrades to existing ones, and service or meter failures. This is why the everyday engagement with technical objects of urban infrastructure networks can be a profitable site of critical inquiry about contemporary urbanism (Farías and Bender, 2010).

In this light, the transition to prepaid electricity being operated in Mozambique, as well as in other African countries, calls for a closer examination of ongoing debates about the politics of urban infrastructures and urban energy in cities of the South. On the one hand, it is in cities of the South where access to electricity is the lowest, with Sub-Saharan Africa at the bottom (IEA, 2011). Hence, the potential for growing demand and network roll-out is the highest there, especially following ongoing calls for improved energy access and security among lower-income populations. Moreover, there is strong support for prepayment of utility services among economists and development and energy specialists, for whom the technology can benefit the energy poor (Estache et al., 2002, Tewari and Shah, 2003, Casarin and Nicollier, 2008).[4] The case of Mozambique thus exemplifies a larger emerging trend: in Africa alone, at least forty-three countries have adopted prepayment for electricity and/or water provision.[5] Yet, transitions to prepayment have not been without contestation regarding energy justice and vulnerability (see below). 
On the other hand, examining the shift to prepayment sheds light on the reshaping of the postcolonial geography of urban infrastructures and livelihoods in cities of the South. It is now fairly established that, in both colonial and post-colonial times, urban infrastructures such as electricity or water have been experienced in cities of the South as fragmented, segregated, visible and politically contested (Gandy, 2006, Coutard, 2008, Jaglin, 2008, Kooy and Bakker, 2008a,b, McFarlane, 2008). This understanding developed in conversation with the long held view that cities of European colonial powers were built on the expectation (and usually the practice) of an integrated, universal, and ubiquitous 'modern infrastructural ideal' (Graham and Marvin, 2001), which was scientifically managed and ultimately rendered invisible over time (Kaika and Swyngedouw, 2000). This ideal was used to order, control and discipline the natives of the colonial territories, both discursively and materially (Mitchell, 1988, Rabinow, 1995). Drawing on discourses of hygiene, public health or need, urban infrastructures were used to spatially segregate the 'civilized' colonizers from the 'primitive' natives and to differentiate between citizens and subjects. In post-colonial contexts, spatial segregation and fragmentation of urban infrastructures continued along class lines through re-worked discourses of civic consciousness, global city competition or sustainability (McFarlane, 2008). It has been argued that this 'modern infrastructural ideal' collapsed in many Euro-American countries since the late 1960s as a result of widespread adoption of liberalization and privatization policies under a turn to neoliberalism (Graham and Marvin, 2001).[6] The impetus towards liberalization and privatization of state-owned water and electricity monopolies imposed on the back of structural adjustments in Africa, Asia and Latin America could be read in that context. However, as noted earlier, the fragmentation of urban infrastructures and the differentiated subjectivities it engendered may have been the dominant rationality of rule already in colonial times, rather than a consequence of a turn to neoliberalism in the postcolonial moment (Kooy and Bakker, 2008a).

In fact, attempts to liberalize energy and water markets in cities of the South have had to compete historically with diverse forms of private and community utility supply (Blundo and Le Meur, 2009). Urban dwellers themselves are actively involved (sometimes even transgressively) in the everyday governance of water and electricity infrastructures, rendering them visible and materially omnipresent through modification of pipes and pumps, illegal connections, wire and cable pilfering, or makeshift fixing of broken network components and devices (Anand, 2011). In African cities, as Simone (2004b) notes, urban infrastructure was never fully materialized or universalized with the expected legibility and rationality as to enforce "specific and consistent territorial organizations of the city" (ibid.: 409). So it is often people, "marginalized and immiserated by urban life" (ibid.: 407), and their diverse activities, who are the infrastructure through which things flow and happen in improvised, flexible, provisional and unstable ways. This is why, in many cities of the South, notions of the 'public/private' divide or of 'citizenship' are entangled with a diversity of forms of allegiance and subject-making, thus remaining elusive and contested realities (Parnell and Pieterse, 2010). Some authors have argued that understanding the politics of urban infrastructures in cities of the South may profit from moving away from such binary discussions (Bakker, 2007, Jaglin, 2008) and a loosening of analytical attention to critiques of neoliberalism (Ferguson, 2009, Parnell and Robinson, 2012, Baptista, 2013).

Instead, theorizing the transition to prepaid electricity in cities like Maputo may thus require that we start off by acknowledging 'slum urbanism' as the dominant urban way of life (Pieterse, 2011) and the historical failure of the 'modern infrastructure ideal' embedded in the largely self-built cities of the South. In other words, understanding contemporary urbanization and its infrastructures in cities of the South requires an examination of the multiple rationalities enacted by urban dwellers in organizing social life, some of which lie outside strict modernist and developmentalist views of the 'good city' (Harrison, 2006). Focusing on the ordinary practices of city-making provides "epistemological reorientation to open up the city differently," as Lawhon et al. (2014: 507) suggested, without losing sight of such central issues as inequality, injustice and uneven development.

Discussions about prepayment of utility services remain, however, deeply entrenched in the normative views underlying the 'modern infrastructural ideal' and in a critique of a turn to neoliberalism. For instance, in the United Kingdom, the increasing use of meters in the 1990s was seen as part of the shift from a social (public) concern with universal utility supply to a marketoriented (private) concern with demand management, cost-recovery and differentiated utility pricing and provision (Marvin and Guy, 1997). The concomitant deployment of prepaid metering for low- 
income households was highly contested for representing the demise of the universal service ethic, for being discriminatory and for increasing the vulnerability of the utility poor through higher pricing and self-disconnections (ibid.).[7] It is unsurprising that when prepayment started being deployed outside of Euro-America it was met with equal skepticism and criticism. In South Africa, which has played a crucial role in developing the prepaid industry since the mid-1980s (Schnitzler, 2013), the roll-out of prepaid utility services in townships has been at the heart of a protracted social and legal conflict, reflecting the country's sensitive post-Apartheid politics. While there are only cursory studies of prepayment outside of South Africa, it is useful to review here the critiques of prepayment emerging there, because, despite the specificities of the context, it illustrates the continuing dominance of the 'modern infrastructural ideal' in critiques of utility service provision.

Critical studies of prepayment in South Africa highlight the demise of the universal utility service ethic under a turn to neoliberalism (McDonald and Ruiters, 2005, McDonald, 2009). These studies criticize customer empowerment narratives associated to prepayment as a way to mask harsh cost-recovery policies that benefit providers alone (McInnes, 2005). Instead of encouraging full citizenship rights and self-determination, critics suggest that prepayment is discriminatory against the poor, seeking to discipline and punish 'unruly' citizens (Ruiters, 2011). They believe prepayment imposes an unfair and unwanted metrological scrutiny, instilling calculation as the essential ethos of citizenship (Schnitzler, 2008). These scholars thus criticize the technology for seemingly allowing the state to distance itself from its responsibilities towards citizens (Heusden, 2009). Some scholarship has tempered these analyses by noting the ambiguous effects of the use of prepaid meters in South African townships, while acknowledging the inequalities embedded in the system (Plancq-Tournadre, 2004, Jaglin, 2008). These authors identify some positive effects to the poor - namely, how prepayment facilitates utility consumption among those with an irregular income and how it helps them stay debt-free, even if only in fragile terms (ibid.). These findings find parallel in research stressing the high value placed by the urban poor on income management and debt-avoidance (Collins et al., 2009). Specifically, Jaglin (2008) noted that the anti-prepayment stance misses the progressive potential of technical differentiation of utility provision in developing countries. In spite of its enduring failure and segregation effects since colonial times, the 'modern infrastructural ideal' thus seemingly persists in examinations of the postcolonial moment.

By examining the Mozambican context, this article contributes to these discussions in three ways. First, it pays attention to a country where utility provision, of electricity in particular, was constituted in relation to context-specific historical processes, which are nonetheless set within wider colonial and postcolonial processes characteristic of Sub-Saharan Africa (see next section). Moreover, focusing on the transition to prepaid electricity in the bairros of Maputo, the article engages with urban conditions not too dissimilar elsewhere in cities of the South: about sixty percent of residential development in the bairros is deemed unplanned (Jenkins, 2012); nearly half of its population is considered to be poor or very poor (ibid.); and about sixty-five percent of the city's workforce relies on informal activities (ibid.). Examining the Mozambican case thus contributes to enlarge the range of urban experiences that informs theorizations of contemporary urbanism (Robinson, 2011).

Second, by focusing on the everyday practices of prepaid electricity, the article explores the multiple ways in which prepaid technology is implicated in organizing social life. As the article's opening story highlights, economic calculation and estimation figure highly in the ability of accessing a valued utility. The article explores what other social relations are being negotiated because, or even in spite of, the transition to prepayment. A closer engagement with how people value and appropriate a utility materially, socially and culturally in everyday life offers insights into what is an 'acceptable' standard of service, both in relation to the meanings ascribed to it and the sense of comfort and convenience derived from its use (Shove, 2003). Such gesture should be taken as complementary, not alternative, to critiques of prepayment that highlight its unfair and discriminatory implications.

Third, much of the sustained attention to the politics of infrastructure in the South focuses on water, as attested by the work referenced so far. Energy infrastructure is only now commanding attention in urban scholarship (e.g. Bridge et al., 2013, Hall et al., 2013, Rutherford and Coutard, 2014), but with very few studies in cities of the South (e.g. Castán Broto and Bulkeley, 2013, Jaglin, 2014, Verdeil, 2014). Examining the shift to prepaid electricity in Maputo in the historical context of Mozambique's electrification and urbanization thus makes a contribution in both directions. 


\section{Electrification of Maputo: colonial and postcolonial challenges and the emergence of prepayment}

Mozambique remains a largely un-electrified country. According to estimates by EDM (2014), only twenty-two percent of the country's population was connected to the grid in 2012. Electricity consumption is geographically uneven across the country: sixty-three percent of the electricity is consumed in the Southern region, where Maputo is located, against twenty-four percent in the Center and thirteen-percent in the North (ibid.). Maputo alone commanded thirty percent of national electricity consumption (ibid.), reflecting its comparatively higher level of urbanization and the economic dynamism of the city and the region. Even though Mozambique registered the second highest growth rate for electricity demand in Southern Africa in 2012, behind Angola, the electricity per capita sold by EDM is about five percent of that sold by Eskom in South Africa (SAPP, 2014).

This state of affairs is rooted in the problematic history of Mozambique's electrification since the late $19^{\text {th }}$-century. Caught up in successive political and economic crisis in mainland Portugal, the colonial administration developed only the bare minimum of infrastructures to facilitate its extractive presence in Mozambique. The colonial administration signed the first concession agreement in 1897 with a private company for the production and distribution of electricity in Lourenço Marques, the colonial designation of Maputo. This happened at the confluence of different forces. First, Lourenço Marques was becoming a prominent urban center in the relations with the mines in the Transvaal. Between 1877 and 1887, the settlement underwent large-scale public works in order to reinforce the services provided by its seaport to the South African republic. Second, following the botched results of the Berlin Conference (1884-5) and the British Ultimatum (1890), the Portuguese made Lourenço Marques the capital city of the colony, so as to to strengthen the occupation of the Southern region and counter British, Dutch and French presence (Newitt, 1995). Lastly, the geopolitical importance of Lourenço Marques was symbolically celebrated by servicing it with the modern means of electric lighting (public and households) and transportation (cable cars) for the enjoyment of its growing 'civilized' population.

In the following decades, electricity services in Lourenço Marques expanded throughout the colonial urban core, but quality was often problematic. The British company holding the concession to the city's electricity and water services run the business for profit, but delivered a poor quality service. Accounts by engineers and public officials at the time derided the electricity system in Lourenço Marques as proper for display in an antiques museum, the scarcity and shortage of electricity "asphyxiating" the city's progress (Santos, 1948). In 1947, at the end of the concession, the colonial administration municipalized electricity distribution, but problems in service quality remained. In part, the material condition of the grid was too poor to cope with industrial development and the growing population.

The problem of electricity supply to the city was addressed only after independence, when the Hydroelectric of Cahora Bassa dam (HCB) came into operation (see Figure 1). Yet, the energy flows between HCB and Maputo were rather circuitous. The dam's financial plan, devised in the 1960s, relied mostly on electricity export to South Africa. For that reason, the transmission infrastructure bypassed Mozambican territory altogether and connected HCB directly to the grid outside of Pretoria. The electricity export agreement established that Lourenço Marques, and later Maputo, would receive electricity from the South African grid at preferential prices via a hook up with the substation in Komatipoort, a South African border town on the railway line to the Transvaal. For the colonial administration, and the new post-colonial government, this arrangement was rather economical and technically desirable. The distance from Lourenço Marques/Maputo to Komatipoort (approx. 100Km) was less than a tenth of the distance to HCB (approx. 1,200 Km). This situation remains the same in 2015, even though changes to the transmission line are apace, including two new connections between Maputo and HCB. 


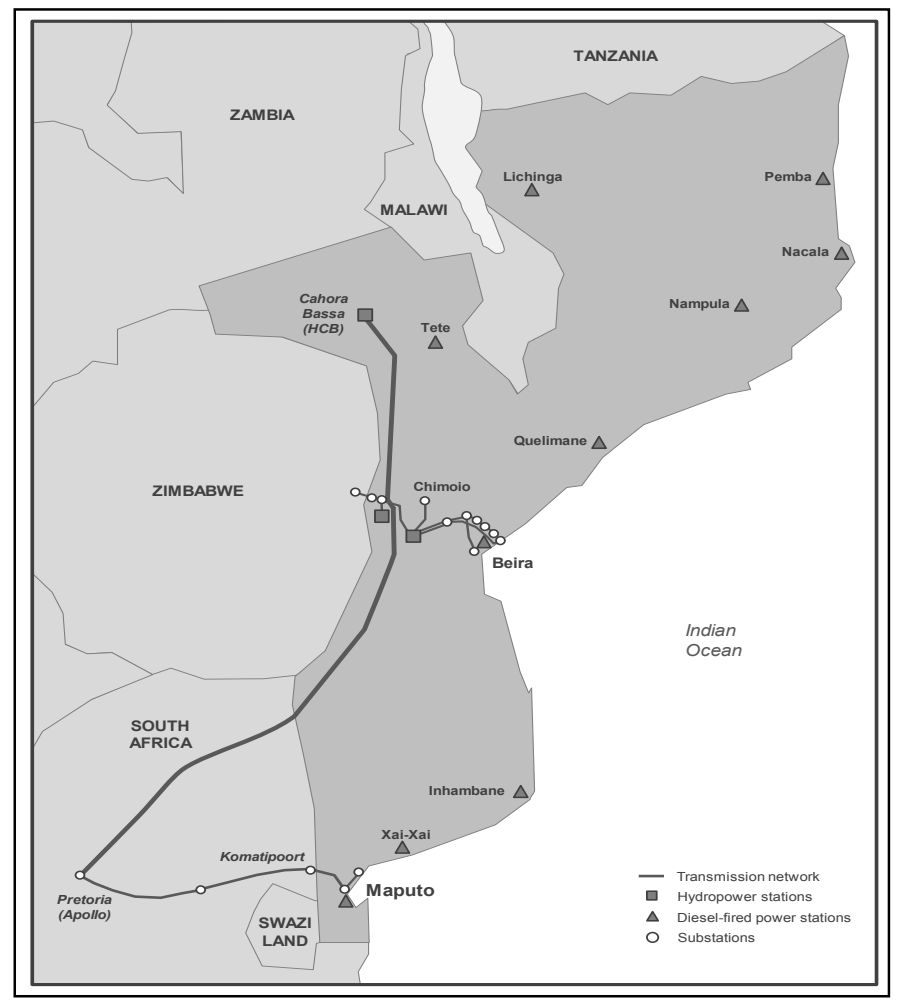

Figure 1. Mozambique's National Electricity Network at Independence (Source: drawn by author based on Dava and Tamele (2011)).

In the beginning, electricity connections were available to a minority of the population living in the dwellings built to European standards in the cidade. The majority of Mozambicans were forced to locate in the bairros surrounding the cidade, in dwellings made of traditional materials, namely reed, without much in the way of infrastructure. For them, the main energy sources were wood/charcoal, kerosene lamps and gas lighting (Dava and Tamele, 2011). Overtime, residents of the bairros converted dwellings into cement block constructions, connecting to the grid in varying degrees of formality and legality. After independence, many families from the bairros moved into apartments in the cidade as part of a state-led initiative to occupy dwellings abandoned by the Portuguese. For many, this may have been the first time they occupied a dwelling fully connected to modern utilities. As Maputo expanded northwards, the grid extended slowly to new areas. Yet, this expansion happened mostly as a result of the endeavors of individual households (see next section).

Prepayment has played a crucial role in the extension of the electricity grid in Maputo. There are no reliable statistics of how many people were connected to the grid in 1995, when prepayment was first introduced, but Araújo (1999) estimated the number at about thirty-eight percent of the city's population for 1997. Anecdotal evidence suggests that some bairros had an entrenched culture of nonpayment with many illegal connections to the grid. In conversations with EDM engineers, electricity pilfering and non-payment was portrayed as problematic for two reasons. It obviously implied foregone revenue, but it also made technical management of electricity supply very difficult, especially in the bairros. It was desirable technically and financially to make the grid more legible and manageable - i.e. to know who was consuming how much and when (to control for peak demand) and to expedite payments (to generate much needed revenue). Mozambique was coming out of nearly sixteen years of civil war (1977-1992), during which the transmission infrastructure connecting HCB to Pretoria had been badly damaged. With no electricity flowing into South Africa to fulfill the export and preferential price agreement, EDM had to buy electricity from Eskom at higher prices to keep Maputo lit. EDM's relatively long and inefficient billing cycle prevented the company from generating the necessary revenues to match the cost paid to Eskom. Prepayment became a solution for this cash-flow problem, as officials at EDM and within the government realized it would be politically difficult to impose higher tariffs on a largely poor population in the post-civil war context. 
The first experiment with the prepaid system Credelec took place in the outskirts of Maputo (at Matola) (see Figure 2), with a pilot project connecting five hundred clients with longstanding debt. It was followed by another project in Maputo proper in 1996, targeting another 5,000 clients. The wider transition to prepayment began in 2005 and reached completion in early 2015. In the intervening decade, all households and small businesses in the bairros and the cidade were fitted with a prepaid meter, much at the same time as the grid reached near universal coverage. Continued improvements in the grid reduced the number of prolonged blackouts, but many instances of current fluctuations persist. With increasing demand from continued urbanization and higher-end real estate projects, blackouts and general energy insecurity may be back again soon.

The transition to prepayment has not been without problems. Prepaid meters are more prone to failure than conventional meters and it is still possible to bypass them to pilfer electricity. Until early 2014, people complained of long waits in line at vending shops and disputed fee charges and tariffs. EDM gradually improved the sales management system, outsourced sales to privately owned vending shop to reach new bairros, and moved into mobile, internet and ATM payment technologies as noted earlier. Prepayment is now accessible 'anytime and anywhere' and urban dwellers in Maputo are seemingly un-phased by the transition. Prepayment is now part of everyday livelihoods, its estimations and calculations in a context of urban uncertainty and provisionality.

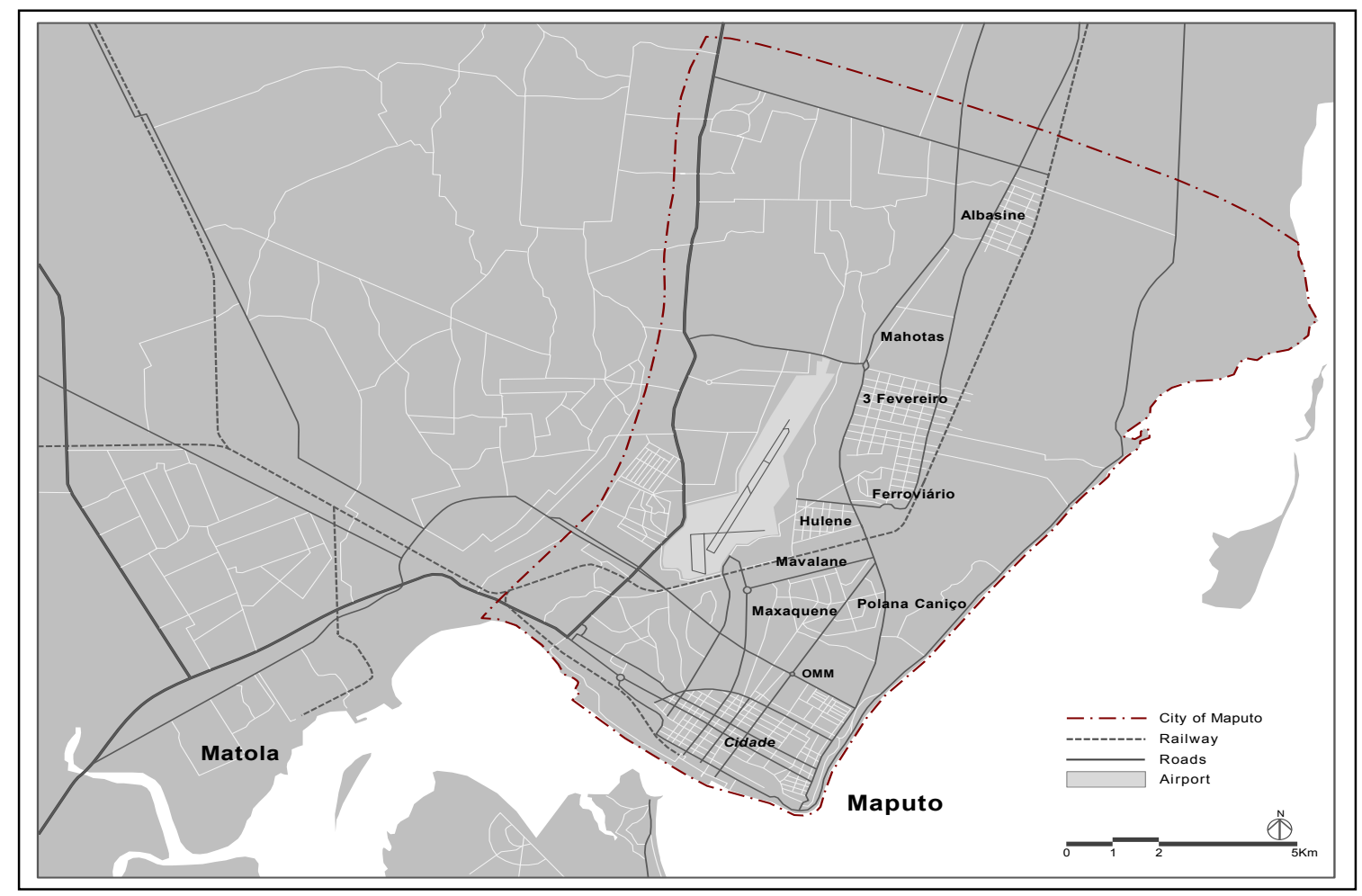

Figure 2. The city of Maputo in context (administrative limits exclude KaTembe and KaNyaka) (Source: drawn by author based on Google Maps).

\section{Everyday electricity practices: productive junctures of urban energy}

\section{The challenges of connecting to the grid}

EDM's statistics of near universal connection to the grid in Maputo are consistent with observations on the ground. The people encountered in the bairros during fieldwork all had access to electricity, even if they used it frugally or had just recently connected to the grid. Francisco was one of the latter 
cases. He had been living since 2009 in a modest house in the bairro Polana Caniço B, a neighborhood adjacent to the cidade. His house is a self-built one-floor dwelling of cement blocks and zinc rooftop, no finishing coat of paint, just like others in the neighborhood. I met Francisco sitting outside the house with his two wives and four of his ten children. Francisco had installed electricity two months before because his children wanted to watch TV and it caused troubles with the neighbors. "The kids like to watch novela (soap opera), movie[s]," he explained. "They go to the neighbor's [house], but [the neighbor] will say that the kids soil the floor. No way to keep that going on! So I decided to put energy in the house."

'To put energy in the house' (pôr energia em casa) is the common expression used by Mozambicans for fitting an electrical installation into homes. What this installation consists of - in number of rooms fitted with lighting fixtures and plugs - will vary according to the household's income. Among the households engaged with during fieldwork, all except those who were tenants had moved into the house prior to it being wired. Sometimes it took several years to save enough money for the installation, other times just a year or two. For instance, it took Francisco four years to get his house wired for electricity use. Inácio, a policeman who located to bairro Mahotas in 1998 after getting married, was seven years without electricity. Like many other Mozambicans, Inácio used candles and kerosene lamps as sources of lighting and charcoal for cooking. Inácio lived with his parents in bairro Hulene until he got married. Their house was fitted with electricity for as long as Inácio remembers, so he was used to having electrical appliances. Fitting electricity in the Mahotas home was a matter of having enough disposable income... and finding a nearby electrical pole or transformer station to connect his house to the grid. Yet, when Inácio first moved to Mahotas, there was hardly anyone living there and the grid did not reach his land plot. If Inácio were to request EDM a connection to the grid, he would have to pay for the actual roll out of the grid up to his door. With no neighbors to pool funds together for such endeavor, Inácio had to wait. In 2005, he finally organized with two neighbors to buy an electrical pole and make the connection. This is not uncommon in Maputo, considering that households often devise life strategies by tapping into a wider network of relatives and individuals with whom they have a diversity of relations (Bénard da Costa and Biza, 2012). Francisco, on the other hand, was lucky that his land plot was located right next to a public lighting pole. When he decided to wire his house, he just had to plug into the pole. However, the installation was costly, nearly USD $\$ 150$, for someone who makes the minimum wage (approx. USD $\$ 100 /$ month) with a job at a private company.

The cases of Francisco and Inácio are illustrative of the wider experience of urban dwellers in Maputo's bairros when 'putting energy in the house'. To Maputo's urban dwellers, accessing electricity seems an inevitable and essential requirement of urban life. But access to electricity requires both their personal endeavor amidst challenging livelihood conditions and an engagement with the enduring infrastructural deficits in the bairros. It is through the everyday practices of electricity consumption that infrastructure in the bairros becomes a productive juncture of Maputo's urban condition, revealing of the experience of urban energy in the city.

\section{Experiencing urban energy: disciplined autonomy, technological literacy and divisibility}

Urban dwellers in Maputo experienced much uncertainty while using electricity with a conventional post-paid meter. Many of those who connected to the grid prior to the mid-1990s (and even well into the early 2000s) were fitted with conventional meters. They reported receiving electricity bills with unanticipated sums to pay, either because the billing covered two or three months of service or because it accounted for an unexpected amount of consumption. These unexpected bills were troublesome on many levels. Households would soon have their electricity account in arrears, because bills could amount to as much as what the breadwinner made in a month. If the household wished to contest the bill, it would have to do so after paying it or risk being fined, disconnected and then have to pay to be reconnected again. Moreover, setting the record straight could involve several trips to EDM, complicated paperwork and procedures that many could not follow, and, more importantly, hours of work and income foregone. In sum, the conventional meter was a headache to many families.

It is in this context that prepaid meters appear to electricity users in the bairros as a welcome change to their relationship with EDM. When asked what they thought of the prepaid system Credelec, most people expressed some form of satisfaction in terms of 'autonomy' or 'control' over 
spending and consumption. For instance, they would favor the prepaid system because they would have unmediated control over how much they spent on electricity and when. People no longer depended on the uncertain performance of EDM regarding billing in order to know how much to pay for electricity. They welcomed avoiding debt too, consuming what they could afford, managing electricity judiciously, while seldom self-disconnecting from the grid. Alberto, an informal worker living in bairro Maxaquene D, explained his use of electricity this way: "I have control over the energy. When it is running out, the little money I have, I'll always go buy [more credit]. I like to leave it at seven or eight $[\mathrm{kWh}]$, which is enough for three days. With Credelec you can control your spending. With the old [conventional meter], you used energy thinking you used 300, 400 [Meticais] and then you got a bill of 500! This way, I'll know how to use [energy]."

'Knowing how to use energy' (saber como usar a energia) often meant that household members had to discipline themselves - individually and each other - about how much electricity they could use each day or over the course of a week or month. In line with existing ethnographic accounts of prepayment (e.g. Schnitzler, 2008), the disciplining took place through controlling, for instance, when lights went on or which appliances were operating at any given time. In some of the households studied, the lights went on at sunset and off right after the novela was over, around 9pm. Raul, an engineer working for an international aid agency, asserted this was a very common practice at Mozambican households. He noted that for many Mozambicans "all that matters is that you go home and you can watch your novela, then the telejornal (the news), and after that another novela." That was the reason why, he assured me, I would see many people lining up at vending shops by $5 \mathrm{pm}$ to buy some 20 Meticais (approx. USD\$0.60) worth of electricity, enough for four or five hours of evening lighting. Individuals exercised this 'disciplined autonomy' of electricity consumption as part of their daily routines and household calculations, thus supporting views that prepaid meters, as technical objects, contribute to organize social life.

In seeking this 'disciplined autonomy' - or as a result of it - individuals became more energy literate and learned to approximate how much electricity was involved in each domestic activity. Ironing was known to 'take up' too much electricity, unlike refrigerators and freezers. Those with electric stoves would turn them on just to warm up leftovers, instead of cooking a full meal. If there were not enough credit left and no one had money available for a top-up, then refrigerators and freezers could be disconnected to reduce consumption or save electricity for watching TV. Even though these situations happened to some of my informants, most of them admitted to finding a way of getting money as soon as possible, even on that same day. Unsurprisingly, once a household is connected to the grid, it is seemingly 'hooked' on electricity.

People also became energy literate in ways seemingly made easier by prepaid technology. It was not that they knew exactly how the electricity system worked, how the meter calculated consumption, or what a $\mathrm{kWh}$ meant. But users knew that with 100 Meticais (approx. USD\$3), they could buy some $30 \mathrm{kWh}$ worth of electricity that would last for a week. While many households consume $30 \mathrm{kWh}$ in less than a week, similar practical knowledge about the triad "money $-\mathrm{kWh}-$ time" can be developed from daily interaction with the meter in view of accounting for household consumption. This is a heuristic individuals can grasp easily in their everyday calculations, irrespective of their level of technical literacy. These findings are in general agreement with theorizations of prepayment as a pedagogical device (Schnitzler, 2008), while further elucidating how - and what - learning occurs through everyday routines.

It is perhaps the divisibility of prepaid electricity - the possibility of buying as many units as one has money for - that makes prepayment a convenient and familiar everyday practice.[8] At local markets, one can find ready-to-buy sets of three bananas for 10 Meticais, four potatoes for 20 Meticais and several other conjugations of food staples, as well as a day's-worth tin of charcoal, washing soap, or rat poison. Being able to buy a day's worth of electricity fits a wider familiar practice, one concurrent with a life dependent on uncertain daily work.

The preference for the divisibility of credit purchases fits within the challenging livelihood conditions of many residents in Maputo's bairros, as illustrated by the case of Manuel, the highschool teacher whose constant calculations opened the introduction to this article. Raul demonstrated this 'accounting' with raw numbers: "An average Mozambican makes 3,000 Meticais a month. You then spend about 900 in electricity, which is for lighting, a refrigerator, a TV, and an iron. To this you have to add the food expenses that an average family of seven spends: 750 for a $25 \mathrm{~kg}$ bag of rice, 450 
for a $25 \mathrm{~kg}$ bag of corn flour, and 300 for 2 bags of pasta. All the food makes up 1,500 (..) and we are mid-way to the monthly budget. Then you also have to pay for water and cellphone!" Prudêncio, who has been unemployed since becoming paraplegic after a nasty mugging near his home in bairro Polana Caniço A, expressed similar concerns. Prior to the assault, Prudêncio's monthly income was also the minimum wage and he spent nearly half of it on the mini-bus transport connections to and from work. Hence, buying small electricity top-ups is a very convenient option for households who must stretch a daily (yet uncertain) income to cover as many goods and services as possible.

While residents of Maputo's bairros will practice divisibility differently depending on their income, the possibility of buying electricity according to the money available also facilitated access to forms of entertainment, convenience and comfort commonly associated with modern livelihoods (cf. Shove, 2003). Inácio, for instance, was well aware that his salary did not allow for a carefree use of electricity at home. But, given the circumstances, prepayment allowed him to reach a certain level of comfort: "Everybody wants to be well in life," Inácio asserted, "[with Credelec] no one is inhibiting me [from using energy]. I'm the one saving it. (...) If I had [a bigger] salary, I wouldn't need to inhibit myself." Ultimately, prepayment allowed urban dwellers to access the 'good life' they aspire to.

Notwithstanding the familiarity, convenience and comfort, the divisibility of electricity prepayment also allowed for the unsettling of social relationships within households in ways that were not simply economic. In a country where patriarchy dominates the social order, prepayment allowed women and younger working males (and females too) to make claims over electricity consumption otherwise unconceivable. Jorge, the oldest son of Prudêncio, and effectively the breadwinner of the household alongside his mother, was able to watch TV, listen to music or play movies on DVDs in his free time unmolested. Margarida, a young housewife in bairro Hulene, admitted to keeping for herself some of the money her father gave her to buy Credelec. Josué, a formal worker at a restaurant chain, admitted to bickering with his eldest son, because he watched too much TV and DVDs. Luísa, Josué's wife, related to me that their son would buy electricity on his own so that the father "would stop complaining." For Jorge, Margarida or Josué's son buying Credelec is a juncture at which they can negotiate their positionality within familial relations.

\section{Prepaid electricity and the politics of the urban condition}

Acknowledging the different facets of prepaid electricity is not a nod in support of privatization of urban services or a gloss over the challenging urban conditions of Maputo's urban dwellers. In fact, those I spoke to were very well aware of their condition and did not glorify it. Conversations about Credelec invariably elicited contemplations rife with political consciousness and reflections on the economic conditions of the household. People recurrently brought up discussions about the wider social and political conditions of the country, the perceived unequal distribution of wealth and resources, the corruption and scandals traversing the political and economic arena or even the contradictions of international policies. For instance, Inácio, the policeman, relayed stories of interference by 'government big-shots' in petty crimes under police investigation; Manuel, the high school teacher, was very critical of the Millennium Development Goals for lowering the substantive quality of education in Mozambique in order to increase the country's literacy numbers. These disparate conversations emerged as we discussed connections to the grid, electricity consumption, or everyday livelihoods in Maputo. They signal the wider political consciousness that can be elicited while using prepaid electricity at junctures other than electricity billing.

Acknowledging the sense of disciplined autonomy prepayment provides to electricity users in Maputo does not forego a critique of social inequality in Mozambican society. Instead, advancing an appreciation of certain aspects of prepayment recognizes the opportunities it provided Maputo households to live what they perceived to be a better off, more dignified livelihood in a context where access to urban infrastructure is markedly an individual (or communal) endeavor. Through its divisibility and the heuristics learned via practical daily engagement with the meter, prepayment provided an opportunity to bring some order into a livelihood pervaded by provisionality and uncertainty. Divisibility also generated possibilities for unsettling existing social relationships within the household and beyond, whether in terms of kinship, gender, or age. Overall, prepayment can be a juncture at which social habits are shaped and (new) social orders invoked. 


\section{Conclusion}

This article examined the case of prepaid electricity in Maputo, Mozambique to reflect on the contemporary geographies of urban energy infrastructure and the urban condition in Sub-Saharan African cities and other cities of the South. Prepayment of utility services is taking root in many African countries and it may expand there and elsewhere as a result of support gathered among development and energy specialists. By inverting the order between consumption and payment for a utility, prepayment challenges a default strategy of the 'modern infrastructural ideal'. As noted earlier, anti-prepayment attitudes seemingly draw much of its criticism from finding this inversion socially unacceptable. As the article exemplified with the case of Maputo, where prepayment is now the universal model of electricity retail, this inversion need not be presumed inherently discriminatory or unfair. By foregrounding the everyday practices of prepaid electricity in the bairros of Maputo, the article highlighted the intersections between the provisional livelihoods of lower-income residents and the fragile condition of urban energy infrastructure in the city and Mozambique as a whole. In this case, prepayment facilitated the translation of everyday estimation and calculation into a desired sense of disciplined autonomy and control over electricity consumption, especially among those with an uncertain daily income. Drawing on simple heuristics and the divisibility of credit purchases inherent to the technology, prepayment enabled urban dwellers to access the comfort and convenience they associate with a decent, 'modern' urban living. This was achieved in large measure as a result of their personal endeavor in search for an improved livelihood, in spite of - or because of - the failure of the 'modern infrastructure ideal' to materialize fully in the bairros by the hand of the state-owned electricity company. The article thus took stock of diverse instances whereby prepayment constituted a juncture for the negotiation of wider social relations. It paid attention to the multiple rationalities implicated in the use of electricity infrastructure and the organization of urban life they engender (and are also a product of). These findings are in line with scholarship discussed earlier casting the antiprepayment attitude as a missed opportunity to see the progressive potential of differential provision of utility services in cities of the South. The adoption of prepayment may even entail possibilities to tackle energy poverty among energy vulnerable populations, if its deployment takes into account issues of equity and justice (Hall et al., 2013).

Notwithstanding the progressive potential of prepayment, it is important to recognize that it does little to address the inequalities and injustices prevailing in Maputo's urbanization and probably elsewhere too. Prepayment offers a promise of future consumption for those who can buy electricity credit, but not the security that electricity will be available for consumption or that it can be consumed regularly and liberally by every household connected to the grid. It is also important to recognize that the energy experience with prepaid electricity in Maputo seemingly stands in contrast with existing insights developed from the South African case. Even within Mozambique, Maputo may stand as a particular case of the experience of energy infrastructure in urban areas. For both reasons, it would be advisable to continue expanding research on contemporary everyday practices of prepaid electricity across a larger number of cities within Mozambique and elsewhere, where the politics of energy infrastructure and urbanization has been constituted differently in historical terms. This can provide a broader comparative view of how and to what extent prepayment is reshaping the post-colonial geography of urban energy infrastructures and urban livelihoods in cities of the South.

\section{References}

Akrich, M. (1992) The De-Scription of Technical Objects. In W.E. Bijker and J. Law (eds.), Shaping Technology/Building Society: Studies in sociotechnical change, MIT Press, Cambridge, MA, 205-24.

Anand, N. (2011) Pressure: The PoliTechnics of water supply in Mumbai. Cultural Anthropology 26, 542-64. 
Araújo, M.G.M.d. (1999) Cidade de Maputo, espaços contrastantes: do urbano ao rural [Maputo city, contrasting spaces: from urban to rural]. Finisterra XXXIV, 175-90.

Bakker, K. (2007) The "Commons" versus the "Commodity": alter-globalization, antiprivatization and the human right to water in the global South. Antipode 39, 430-55.

Baptista, I. (2013) The travels of critiques of neoliberalism: urban experiences from the 'borderlands'. Urban Geography 34, 590-611.

Barry, A. (2001) Political Machines: Governing a Technological Society. The Athlone Press, London, UK.

Bénard da Costa, A. and A. Biza (2012) Home Space: Ethnographic Report. The Royal Danish Academy of Fine Arts, School of Architecture, Department of Human Settlements, Copenhagen, Denmark.

Blundo, G. and P.-Y. Le Meur (eds.) (2009) The Governance of Daily Life in Africa: Ethnographic Explorations of Public and Collective Services. Brill, Leiden, The Netherlands.

Bridge, G., S. Bouzarovski, M. Bradshaw and N. Eyre (2013) Geographies of energy transition: space, place and the low-carbon economy. Energy Policy 53, 331-40.

Casarin, A.A. and L. Nicollier (2008) Prepaid meters in electricity: a cost-benefit analysis. IAE Business School, Austral University Working paper.

Castán Broto, V. and H. Bulkeley (2013) Maintaining climate change experiments: Urban Political Ecology and the everyday reconfiguration of urban infrastructure. International Journal of Urban and Regional Research 37, 1934-48.

Collins, D., J. Morduch, S. Rutherford and O. Ruthven (2009) Portfolios of the poor: How the world's poor live on $\$ 2$ a day. Princeton University Press, Princeton, NJ.

Coutard, O. (2008) Placing splintering urbanism: Introduction. Geoforum 39, 1815-20.

Dava, F. and V. Tamele (2011) História dos 30 Anos da Electricidade de Moçambique, E.P. [History of the 30 Years of Electricidade de Moçambique, E.P.]. EDM, Electricidade de Moçambique, Maputo, Moçambique.

EDM (2014) Sumário Estatístico / Statistical Summary 2012. Electricidade de Moçambique, E.P., Maputo, Moçambique.

Estache, A., V. Foster and Q. Wodon (2002) Accounting for Poverty in Infrastructure Reform: Learning from Latin America's Experience. World Bank, Washington, D.C.

Farías, I. and T. Bender (eds.) (2010) Urban Assemblages: How Actor-Network Theory Changes Urban Studies. Routledge, London, UK.

Ferguson, J. (2009) The uses of neoliberalism. Antipode 41, 166-84.

Gandy, M. (2004) Rethinking urban metabolism: water, space and the modern city. City 8 , 363-79.

Gandy, M. (2006) Planning, anti-planning and the infrastructure crisis facing metropolitan Lagos. Urban Studies 43, 371-96.

Graham, S. and S. Marvin (2001) Splintering Urbanism: Networked Infrastructures, Technological Mobilities, and the Urban Condition. Routledge, London, UK.

Hall, S.M., S. Hards and H. Bulkeley (2013) New approaches to energy: equity, justice and vulnerability. Introduction to the special issue. Local Environment 18, 413-21.

Harrison, P. (2006) On the edge of reason: planning and urban futures in Africa. Urban Studies 43, 319-35.

Harvey, D. (1996) Cities or urbanization? City 1, 38-61.

Harvey, D. (2005) A Brief History of Neoliberalism. Oxford University Press, New York, NY.

Henriques, C.D. (2008) Maputo: Cinco décadas de Mudança Territorial [Maputo: Five Decades of Territorial Change]. Instituto Português de Apoio ao Desenvolvimento, Lisboa, Portugal. 
Heusden, P.v. (2009) Discipline and the new 'logic of delivery': prepaid electricity in South Africa and beyond. In D.A. McDonald (ed.), Electric Capitalism: Recolonising Africa on the Power Grid, Earthscan, London, UK and Cape Town, South Africa, 229-47.

Hughes, T.P. (1983) Networks of Power: Electrification in Western Society, 1880-1930. The Johns Hopkins University Press, Baltimore, Md.

IEA (2011) World Energy Outlook 2011 - Energy for All: Financing access for the poor. International Energy Agency, Paris, France.

Jaglin, S. (2008) Differentiating networked services in Cape Town: Echoes of splintering urbanism? Geoforum 39, 1897-906.

Jaglin, S. (2014) Urban energy policies and the governance of multilevel issues in Cape Town. Urban Studies 51, 1394-414.

Jenkins, P. (2012) Home Space: Context Report. The Royal Danish Academy of Fine Arts, School of Architecture, Department of Human Settlements, Copenhagen, Denmark.

Kaika, M. and E. Swyngedouw (2000) Fetishizing the modern city: the phantasmagoria of urban technological networks. International Journal of Urban and Regional Research 24, 120-38.

Kooy, M. and K. Bakker (2008a) Splintered networks: the colonial and contemporary waters of Jakarta. Geoforum 39, 1843-58.

Kooy, M. and K. Bakker (2008b) Technologies of government: constituting subjectivities, spaces, and infrastructures in colonial and contemporary Jakarta. International Journal of Urban and Regional Research 32, 375-91.

Lawhon, M., H. Ernstson and J. Silver (2014) Provincialising Urban Political Ecology: expanding Urban Political Ecology through African urbanism. Antipode 46, 497-516.

Marres, N. (2012) Material Participation: Technology, the Environment and Everyday Publics. Palgrave Macmillan, Basingstoke, UK.

Marvin, S. and S. Guy (1997) Consuming water: evolving strategies of water management in Britain. Journal of Urban Technology 4, 21-45.

McDonald, D.A. (ed.) (2009) Electric Capitalism: Recolonising Africa on the Power Grid. Earthscan and Humans Sciences Research Council Press, London, UK and Cape Town, South Africa.

McDonald, D.A. and G. Ruiters (eds.) (2005) The Age of Commodity: Water Privatization in Southern Africa. Earthscan, London, UK.

McFarlane, C. (2008) Governing the contaminated city: infrastructure and sanitation in colonial and post-colonial Bombay. International Journal of Urban and Regional Research 32, 415-35.

McInnes, P. (2005) Entrenching inequalities: the impact of corporatization on water injustices in Pretoria. In D.A. McDonald and G. Ruiters (eds.), The Age of Commodity: Water Privatization in Southern Africa, Earthscan, London, UK, 99-119.

Melosi, M.V. (2000) The Sanitary City: Urban Infrastructure in America from Colonial Times to the Present. The Johns Hopkins University Press, Baltimore, MD.

Mitchell, T. (1988) Colonising Egypt. University of California Press, Berkeley, CA.

Myers, G. (2011) African Cities: Alternative Visions of Urban Theory and Practice. Zed Books Ltd., London, UK.

Newitt, M. (1995) A History of Mozambique. Hurst \& Company, London, UK.

Parnell, S. and E. Pieterse (2010) The 'right to the city': institutional imperatives of a developmental State. International Journal of Urban and Regional Research 34, 14662.

Parnell, S. and J. Robinson (2012) (Re)Theorizing cities from the global South: looking beyond neoliberalism. Urban Geography 33, 593-617. 
Paulo, M., C. Rosário and I. Tvedten (2011) 'Xiculungo' Revisitado: Avaliando as implicações do PARPA II em Maputo 2007-2010 ['Xiculungo' Revisited: Evaluating the implications of PARPA II in Maputo 2007-2010]. CMI, Chr. Michelsen Institute, Bergen, Norway.

Pieterse, E. (2011) Rethinking African urbanism from the slum. Urban Age Conference "Cities, Health and Well-Being", LSE Cities, Hong Kong, China.

Plancq-Tournadre, M. (2004) Services d'eau et d'électricité au Cap, ou comment la sortie de l'apartheid fabrique des débranchés [Water and electricity in the Cape, or how the end of apartheid produces the disconnected]. Flux 56-57, 13-26.

Platt, H.L. (1991) The Electric City: Energy and the Growth of the Chicago Area, 1880-1930. The University of Chicago Press, Chicago, IL.

Rabinow, P. (1995) French Modern: Norms and Forms of the Social Environment. The University of Chicago Press, Chicago, IL.

Robinson, J. (2011) 2010 Urban Geography Plenary Lecture - The travels of urban neoliberalism: taking stock of the internationalization of urban theory. Urban Geography 32, 1087-109.

Ruiters, G. (2011) Developing or managing the poor: the complexities and contradictions of free basic electricity in South Africa (2000-2006). Africa Development XXXVI, 11942.

Rutherford, J. and O. Coutard (2014) Urban energy transitions: places, processes and politics of socio-technical change. Urban Studies 51, 1353-77.

Santos, M.P.P.d. (1948) Posição de Lourenço Marques num futuro esquema de electrificação do Sul do Save [Positionality of Lourenço Marques on a future electrification scheme for the South Save]. 2. ${ }^{\circ}$ Congresso Nacional de Engenharia, Porto, Portugal.

SAPP (2014) Southern African Power Pool 2013 Annual Report. Southern African Power Pool, Harare, Zimbabwe.

Schnitzler, A.v. (2008) Citizenship prepaid: water, calculability, and techno-politics in South Africa. Journal of Southern African Studies 34, 899-917.

Schnitzler, A.v. (2013) Traveling technologies: infrastructure, ethical regimes, and the materiality of politics in South Africa. Cultural Anthropology 28, 670-93.

Shove, E. (2003) Comfort, Cleanliness and Convenience: The Social Organization of Normality. Berg, Oxford, UK.

Simone, A. (2004a) For the City Yet to Come: Changing African Life in Four Cities. Duke University Press, Durham, NC.

Simone, A. (2004b) People as infrastructure: intersecting fragments in Johannesburg. Public Culture 16, 407-29.

Swyngedouw, E. (1996) The city as a hybrid: on nature, society and cyborg urbanisation. Capitalism Nature Socialism 7, 65-80.

Tewari, D.D. and T. Shah (2003) An assessment of South African prepaid electricity experiment, lessons learned, and their policy implications for developing countries. Energy Policy 31, 911-27.

Verdeil, É. (2014) The contested energy future of Amman, Jordan: between promises of alternative energies and a nuclear venture. Urban Studies 51, 1520-36.

White, L.A. (1943) Energy and the evolution of culture. American Anthropologist 45, 335-56. 


\section{Endnotes}

[1] The cidade is the consolidated core of Maputo built to European standards in the colonial period (see Figure 2). It corresponds to about $8 \%$ of Maputo's area today, and it is home to about $10 \%$ of its population (Henriques, 2008). At Independence, the area of the cidade was proportionally larger (about 20\%), because the corresponding administrative area was smaller than today (ibid.). Mozambicans distinguish between cidade and neighborhoods outside of it - the bairros or subúrbios, which they use interchangeably nowadays - where the majority resides since colonial times. It would be a gross simplification to designate bairros or subúrbios as informal settlements due to the diversity of (in)formalities in Maputo (Jenkins, 2012). For simplicity, I use bairros to refer to all neighborhoods outside the cidade. By 'Maputo' or 'city of Maputo', I mean both bairros and cidade.

[2] Paulo et al. (2011) estimate the average monthly income in Maputo in 2009 was about USD\$46, with the lower $20 \%$ and the upper $20 \%$ making respectively about USD 13 and USD \$ 140 .

[3] The nine bairros are located on Maputo's Northern urban development corridor (Figure 2). The six vending shops are: EDM Sede, EDM FPLM, Galp OMM, Contentor OMM, Farmácia Polana Caniço and Galp Xiquilene. The households studied were selected in the vicinity of sampling points of the Home Space research project, led by Jørgen Andersen and Paul Jenkins. The author deemed the area covered by their project appropriate as a starting point for the fieldwork because it entails a representative sample of the urban dynamics of the city of Maputo in terms of household income structure, land tenure security and urban planning and development status (Jenkins, 2012). Households studied were selected randomly, attempting to capture different income levels and gender and age ranges. At the vending shops, participants were selected according to similar principles. Because participants at the vending shops were interviewed while waiting in line (between 15-60 minutes wait), the depth and engagement with the participants was not as extensive as that of the household interviews. In both cases, the semi-structured interviews focused on electricity consumption and the conditions of the household. Informants in the electricity sector were selected for their roles at EDM or at public or international organizations related to energy and urban development. Semi-structured interviews with these informants focused on electricity provision and broader energy policy in Mozambique. All participant names were changed for identity protection.

[4] These specialists highlight the advantages of prepayment in contexts of weak governments, scant land use/infrastructure planning, unclear land tenure, and persistent poverty. They suggest that prepayment can empower poorer customers to manage better their income and stay debt-free, while generating revenue and improving customer relationships, especially in areas where there may be high rates of utility pilfering. Prepayment supporters recognize that improvements in users' welfare may involve changes in consumption habits (e.g. self-control of appliance use). They also note that unexpected problems may occur, including meter failures, meter tampering, vendor fraud, and social conflict in highly politicized contexts.

[5] The author developed this indicative (non-representative) assessment via an analysis of online reports on prepaid electricity and water in all African countries.

[6] I follow Harvey (2005: 2) in defining neoliberalism as "in the first instance a theory of political economic practices that proposes that human well-being can best be advanced by liberating individual entrepreneurial freedoms and skills within an institutional framework characterized by strong private property rights, free markets, and free trade."

[7] Yet, 'penny-in-the-slot' prepaid meters had been used in UK working-class neighborhoods since the late $19^{\text {th }}$-century (Schnitzler, 2013).

[8] Luís Lage, a Professor of Architecture and Planning at Mozambique's Eduardo Mondlane University, was the first to call my attention to the importance of divisibility in Mozambique. 